\title{
Safety of anticoagulation in the elderly: reasons for discontinuing therapy
}

\author{
P.A. O’Neill, D. Crossley, D.A. Taberner and D.S. Fairweather* \\ University Hospital of South Manchester, Nell Lane, Manchester M20 8LR, UK
}

Summary: We have conducted a retrospective study on the reasons for discontinuing anticoagulants in 50 patients over the age of 75 years compared with 198 adults under 75 years to determine the safety of $\subseteq$ therapy in the elderly. Venous thromboembolism and arterial embolization were the most common indications for therapy in the elderly and the median duration of therapy in all patients was 7 months $(9 \%$ days-22 years). There were no deaths attributable to anticoagulants. There was no significant difference $\dot{0}$ in the proportion of elderly patients who stopped treatment because of bleeding compared with 198 patients under 75 years $(5 / 50(10 \%)$ vs $12 / 198(6.1 \%), P=0.26)$, nor in the rate of bleeding between the two groups $(5 / 52.5(9.5 \%)$ treatment-years vs $12 / 249(4.8 \%)$ treatment-years, $P=0.15)$. This complication rate does not suggest that age per $s e$ is a risk factor in the use of oral anticoagulants.

\section{Introduction}

It is commonly believed that the risk of bleeding whilst receiving anticoagulants is dependent on the age of the patient, a point of view that was reinforced by recent reviews. ${ }^{1,2}$ The evidence on which this is based was published a number of years ago and the degree of control was probably poor with some centres using inappropriately high levels of anticoagulation. ${ }^{3,4}$ The analyses presented often did not examine for age as an independent variable. Levine et al. ${ }^{5}$ in 1986 summarized the more recent studies and concluded that no definite relationship could be found between the risk of bleeding and age alone, since the majority of published reports have lacked the necessary information.

We have performed a retrospective study to assess the safety of treating elderly patients with anticoagulants in routine clinical practice.

\section{Methods}

In our district all oral anticoagulant therapy is monitored by a laboratory-based clinic and supervised by consultant haematologists. Control is monitored by established criteria ${ }^{6}$ and the majority

Correspondence: P.A. O'Neill, M.R.C.P., M.D., Department of Geriatric Medicine, University Hospital of South Manchester, Nell Lane, Manchester M20 8LR, UK.

*Present address: Radcliffe Infirmary, Oxford, UK.

Accepted: 15 April 1992
(73.3\%) of prothrombin time estimations are in desired range (International normalized ratio INR, 2-4.5). The records of 50 consecutois patients over the age of 75 years who stoppeds nicoumalone were examined together with those of 198 consecutive patients under 75 years also stop ping treatment. These patients were identified from the anticoagulant records covering one year. The following information was recorded: (1) indication for therapy; (2) duration of therapy; (3) degree of control, which was assessed by estimating the length of time the INR of each patient was in the range 2-4.5 excluding stabilization and tailing off periods. The estimated time in the therapeuticrange was calculated using the midpoint betweens measured values to the next midpoint. (4) Reasonsh for discontinuation, if indicated in the notes.

Both the absolute incidence of bleeding complications and the rate of bleeding were compared (Fisher's exact test) to the incidence and bleedins rate for the younger patients. The occurrence of bleeding was established by examination of the cases notes and clinic record cards. The rate of bleeding was calculated by using the number of years thaf patients had been exposed to therapy.

\section{Results}

\section{(1) Reasons for discontinuation}

The median age of the elderly patients was 80 years (range 75-90) and of the younger group 57 years 
(range $15-74$ ). In $65 \%$ of the old and $74 \%$ of the young group the reason for discontinuation of therapy was an elective medical one taken by the clinical team. There were eight deaths in the old group and 24 in the young on therapy: none of these appeared directly related to the treatment, though in seven of the young group the cause of death could not be ascertained.

In the elderly group six patients had their therapy stopped for social reasons, for example, difficulty in attending clinic, and in three of these the decision was made prior to discharge. This compared with nine patients in the young group. One elderly person and three young patients refused further treatment. In two of the elderly group and 15 of the young group the reasons for discontinuation were unknown (Table I).

There were five elderly and 12 young patients who developed bleeding whilst receiving treatment (see Table II); none was fatal. All patients had been anticoagulated for at least 6 months. There was no difference in the proportion of elderly patients who stopped treatment because of bleeding compared with those less than 75 years $(5 / 50(10 \%)$ vs $12 / 198$ $(6.1 \%), P=0.26,95 \% \mathrm{CI}$ for difference in proportions -0.05 to 0.13 ) nor in the rate of bleeding between the two groups (5/52.5 treatment-year $v s$ $12 / 249$ treatment-year, $P=0.15,95 \%$ CI for difference in proportions -0.04 to 0.13 ).

\section{(2) Indications for therapy}

The main indication in the elderly for anticoagulation was venous thromboembolism, either deep vein thrombosis (single episode 21 patients, recurrent three patients) or pulmonary embolism (seven patients). A similar spectrum of indications was seen in the younger patient group (Table III), though a greater proportion of the latter received therapy following myocardial infarction for heart failure and for valvular heart disease.

The median duration of therapy was 7 months with a range of 9 days to 22 years. The median and ranges for the different indications are given in Table III.

\section{(3) Degree of control}

On average each elderly patient was optimally controlled for $73.5 \%$ of the time $(25-100 \%)$ compared with $74.7 \%(15-100 \%)$ in the young. In the five elderly patients who bled (see below) the percentage of time the INR was in the target therapeutic range $(2-4.5)$ varied between 60 and $95 \%$ of the time (mean $69 \%$ ) compared with between 55 and $97 \%$ (mean $62 \%$ ) for the 12 young patients. At the time of the bleeding episode none had an INR above the target range. In all patients
Table I Comparison of the reasons for discontinuing anticoagulants in young and old patients

\begin{tabular}{lcr}
\hline Reason & Young & Old \\
\hline Bleed & 12 & 5 \\
Elective & 135 & 28 \\
Died on therapy & 24 & 8 \\
Social & 9 & 6 \\
Refusal & 3 & 1 \\
Unknown & 15 & 2 \\
\hline
\end{tabular}

attending the clinic the proportion with an INR in the therapeutic range was $73.7 \%$.

\section{Discussion}

In this series of patients discontinuing oral anticoagulants, which is based on a large teaching hospital practice, we could find no clear relationship between age and the proportion of patients who bled, nor with the bleeding rate according to the length of exposure to treatment. There were no deaths definitely attributable to anticoagulants. It is possible that the power of the study was insufficient to detect a small association with age. The retrospective design may also have led to bias as only those patients discontinuing therapy were studied. Differing results might have been obtained if the design had been to examine prospectively reasons for discontinuing anticoagulants in a cohort of patients started on therapy.

It is known that elderly people require a lower maintenance dose of anticoagulant ${ }^{7}$ possibly due to an increased receptor affinity for these agents. ${ }^{8}$ Furthermore, the general incidence of adverse drug reactions rises with age, ${ }^{9}$ possibly due to increased drug interactions. However, the evidence that age per se increases the risk of bleeding from anticoagulants is lacking. Published studies on the safety of treatment were reviewed by Levine $e t$ al. ${ }^{5}$ in 1986 and their general comments were that in the majority there were insufficient data in crucial areas such as duration of therapy and control obtained for analysis to be performed. An attempt was also made by Levine et al..$^{5}$ to look at age as an independent factor but again it was found that there were insufficient data in the international published studies for analysis. A previous large study had concluded that there was no relationship between age and the risk of bleeding complications. ${ }^{10}$ The data from Wickramasinghe et al. ${ }^{11}$ would support this, but a more recent paper ${ }^{12}$ found an eight-fold increase in the risk of a cerebral haemorrhage after the age of $\mathbf{5 0}$ years, though this was unrelated to the degree of anticoagulation. 
Table II Details of the five older patients (nos 1-5) and the 12 younger patients (6-17) who discontinued 3 anticoagulants due to bleeding. (See text for details on control)

\begin{tabular}{|c|c|c|c|c|c|c|c|}
\hline $\begin{array}{l}\text { Subject } \\
\text { no. }\end{array}$ & Age & Indication & $\begin{array}{l}\text { Duration } \\
\text { (months) }\end{array}$ & $\begin{array}{c}\text { Control } \\
(\%)\end{array}$ & $\begin{array}{l}\text { INR at time of } \\
\text { bleeding }\end{array}$ & Complication & Outcome \\
\hline 1 & 75 & $\begin{array}{l}\text { Atrial fibrillation } \\
\text { and emboli }\end{array}$ & 6 & 60 & 2.3 & Haematemesis & $\begin{array}{l}\text { Therapy } \\
\text { stopped }\end{array}$ \\
\hline 2 & 84 & $\begin{array}{l}\text { Recurrent deep } \\
\text { vein thrombosis }\end{array}$ & 20 & 96 & 1.7 & Haematemesis & $\begin{array}{l}\text { Therapy } \\
\text { stopped }\end{array}$ \\
\hline 3 & 87 & $\begin{array}{l}\text { Transient } \\
\text { ischaemic attack }\end{array}$ & 26 & 63 & 3.9 & $\begin{array}{l}\text { Intraocular } \\
\text { bleeding }\end{array}$ & $\begin{array}{l}\text { Blind one } \\
\text { eye. } \\
\text { Therapy } \\
\text { stopped }\end{array}$ \\
\hline 4 & 83 & Arterial embolus & 9 & 60 & 2.8 & Melaena & $\begin{array}{l}\text { Therapy } \\
\text { stopped. } \\
\text { Died } \\
\text { stroke } \\
10 \text { days }\end{array}$ \\
\hline 5 & 82 & $\begin{array}{l}\text { Lone atrial } \\
\text { fibrillation }\end{array}$ & 6 & 66 & 4.4 & Melaena & $\begin{array}{l}\text { Therapy } \\
\text { stopped } \\
\text { tempor- } \\
\text { arily }\end{array}$ \\
\hline 6 & 69 & Atrial fibrillation & 27 & 55 & 3.9 & Haematemesis & $\begin{array}{l}\text { Therapy } \\
\text { stopped }\end{array}$ \\
\hline 7 & 73 & Myocardial infarct & 6 & 55 & 3.5 & $\begin{array}{l}\text { Intracerebral } \\
\text { bleed }\end{array}$ & $\begin{array}{l}\text { Therapy } \\
\text { stopped }\end{array}$ \\
\hline 8 & 55 & $\begin{array}{l}\text { Recurrent deep } \\
\text { vein thrombosis }\end{array}$ & 20 & 56 & 4.5 & Melaena & $\begin{array}{l}\text { Therapy } \\
\text { stopped } \\
\text { tempor- } \\
\text { arily }\end{array}$ \\
\hline 9 & 49 & Pulmonary embolus & 7 & 60 & 2.3 & Epistaxis & $\begin{array}{l}\text { Therapy } \frac{C}{\text { stopped }}\end{array}$ \\
\hline 10 & 65 & $\begin{array}{l}\text { Emboli with atrial } \\
\text { fibrillation }\end{array}$ & 60 & 57 & 4.4 & Melaena & $\begin{array}{l}\text { Therapy } \\
\text { stopped }\end{array}$ \\
\hline 11 & 59 & Myocardial infarct & 10 & 70 & 4.1 & Melaena & $\begin{array}{l}\text { Therapy } \\
\text { stopped }\end{array}$ \\
\hline 12 & 47 & Pulmonary embolus & 35 & 56 & 4.0 & Haematemesis & $\begin{array}{l}\text { Therapy } \\
\text { stopped } \\
\text { tempor- } \\
\text { arily }\end{array}$ \\
\hline 13 & 63 & Arterial emboli & 60 & 56 & 2.9 & Melaena & $\begin{array}{l}\text { Therapy } \\
\text { stopped }\end{array}$ \\
\hline 14 & 67 & $\begin{array}{l}\text { Mitral valve } \\
\text { disease }\end{array}$ & 80 & 57 & 4.4 & Haematemesis & $\begin{array}{l}\text { Therapy } \\
\text { stopped } \\
\text { tempor- } \\
\text { arily }\end{array}$ \\
\hline 15 & 71 & Myocardial infarct & 6 & 97 & 3.2 & Haematemesis & $\begin{array}{l}\text { Therapy } \\
\text { stopped }\end{array}$ \\
\hline 16 & 66 & Heart failure & 25 & 62 & 2.7 & Melaena & $\begin{array}{l}\text { Therapy } \\
\text { stopped }\end{array}$ \\
\hline 17 & 63 & DVT & 6 & 58 & 2.1 & Melaena & $\begin{array}{l}\text { Therapy } \\
\text { stopped }\end{array}$ \\
\hline
\end{tabular}

Many would feel that the risk/benefit ratio for the use of oral anticoagulants even for the standard indications have not been generally established at any age. ${ }^{1,2}$ Most studies have been poorly designed, have not included their criteria for optimum therapy and the results presented have been lacking in detail so that critical analysis is not possible.
Furthermore, criteria for adequate control has $\stackrel{\varrho}{\circ}$ changed, ${ }^{6}$ especially since the introduction of the INR $^{13}$ so that results from previous studies, particularly from North America where high intensity 0 treatment has generally been used, ${ }^{14}$ are hard to $\mathbb{D}$ interpret, and probably do not reflect the risks $\frac{\Omega}{\mathbb{D}}$ applicable to common practice elsewhere. 
Table III Indication for therapy, numbers, median duration of treatment (months) and the range for the younger $(n=198)$ and older $(n=50)$ patients

\begin{tabular}{lcccc}
\hline Indication & $n$ & $\begin{array}{c}\text { Younger } \\
\text { Duration (months) } \\
\text { median (range) }\end{array}$ & $n$ & $\begin{array}{c}\text { Older } \\
\text { Duration (months) } \\
\text { median (range) }\end{array}$ \\
\hline $\begin{array}{l}\text { Deep vein } \\
\text { thrombosis }\end{array}$ & 63 & $2(0.5-17)$ & 21 & $2(0.7-6)$ \\
$\begin{array}{l}\text { Recurrent deep } \\
\text { vein thrombosis }\end{array}$ & 13 & $6(2-27)$ & 3 & $8(3-25)$ \\
$\begin{array}{l}\text { Pulmonary } \\
\text { embolus }\end{array}$ & 39 & $6(1-84)$ & 7 & $8(1-93)$ \\
$\begin{array}{l}\text { Myocardial } \\
\text { infarction }\end{array}$ & 24 & $3(0.5-15)$ & 2 & $2(1-3)$ \\
$\begin{array}{l}\text { Emboli with } \\
\text { atrial } \\
\text { fibrillation }\end{array}$ & 13 & $48(3-190)$ & 4 & $15(0.5-180)$ \\
$\begin{array}{l}\text { Emboli with } \\
\text { sinus rhythm }\end{array}$ & 7 & $48(3-264)$ & 6 & $25(1-200)$ \\
$\begin{array}{l}\text { Lone atrial } \\
\text { fibrillation }\end{array}$ & 14 & $6(4-12)$ & 4 & $5(2-18)$ \\
$\begin{array}{l}\text { Transient } \\
\text { ischaemic } \\
\text { attack }\end{array}$ & 2 & $3(1-5)$ & 2 & $4(2-6)$ \\
$\begin{array}{l}\text { Mitral valve } \\
\text { disease }\end{array}$ & 13 & $72(4-144)$ & 1 & 93 \\
$\begin{array}{l}\text { Heart failure } \\
\text { Renal } \\
\text { failure/shunt }\end{array}$ & 7 & $5(2-37)$ & - & - \\
Total & 3 & $7(2.53)$ & 50 & - \\
\hline
\end{tabular}

There is even less information on the maximum duration of therapy for the greatest benefit to be had. Forfar ${ }^{9}$ suggested that the rate of complications increased with length of exposure. In our study the duration of therapy, although not statistically significant, was greater in those that bled. Some patients, for example, those with thromboembolism, may have been overtreated. ${ }^{15}$

We would agree with $S c o t t^{2}$ that evidence for the efficacy of anticoagulants in the elderly should be obtained from prospective randomized clinical studies and that anticoagulants should not be withheld on the grounds of age alone. The view that 'social factors' would preclude a large number of elderly people from receiving therapy ${ }^{4}$ is erroneous, though some selection may have operated in those elderly patients eligible for therapy. The belief that old people are generally less compliant than the young is questionable, yet this view is still widely held. ${ }^{16}$

We have found no evidence that age per se is a contraindication to anticoagulation. It is more important to consider other risk factors such as hypertension or recent gastrointestinal bleeding in making a decision to treat with anticoagulants and, though many of these are associated with ageing, they are not exclusively the preserve of the elderly.

\section{References}

1. Lowe, G.D.O. Anticoagulants in the elderly: valuable in selective patients. $\mathrm{Br}$ Med J 1988, 297: 1260.

2. Scott, P.J.W. Anticoagulants in the elderly: the risks usually outweigh the benefit. Br Med J 1988, 297: 1261.

3. Coon, W.W. \& Willis, P.W. Haemorrhagic complications of anticoagulant therapy. Arch Intern Med 1974, 133: 386-392.

4. Pollard, J.W., Hamilton, M.J. \& Christenson, N.A. Problems associated with long-term anticoagulant therapy. Circulation 1962, 25: 311-317.

5. Levine, M.N., Raskob, G. \& Hirsch, J. Haemorrhagic complications of long-term anticoagulant therapy. Chest 1986, 89: 16-25S.

6. Poller, $L$. Therapeutic ranges in anticoagulant administration. $B r$ Med J 1985, 290: 1683-1686.

7. Redwood, M., Taylor, C., Bain, B.J. \& Mathews, J.H. The association of age with dosage requirements for Warfarin. Age Ageing 1991, 20: 217-220. 
8. O'Malley, K., Stevenson, I.H., Ward, C.A., Wood, A.J. \& Crooks, J. Determinants of anticoagulant control in patients receiving Warfarin. Br J Clin Pharmacol 1977, 4: 309-314.

9. Caird, F.I. \& Scott, P.J.W. Drug-induced Diseases in the Elderly: A Critical Survey of the Literature. Elsevier, Amsterdam, 1986

10. Forfar, J.C. A long-term analysis of haemorrhage in patients on long-term anticoagulant treatment. Br Heart $J$ 1979, 42: $128-132$.

11. Wickramasinghe, L.S.P., Basu, S.K. \& Bansal, S.K. Longterm anticoagulant therapy in elderly patients. Age Ageing 1988, 17: 388-396.

12. Franke, C.L., de 'Jange, J., van Swieten, J.C., Op de Cal, A.A. \& van Gijn, J. Intercerebral hematomas during anticoagulant treatment. Stroke 1990, 21: 726-730.
13. Poller, L. INR and the therapeutic range. Biologia Cli Haematolog 1987, 9: 203-213.

14. Poller, L. \& Taberner, D.A. Dosage and control of ora anticoagulants: an international survey. Br J Haem 1982, 51 479-485.

15. Holmgren, K., Andersson, G., Fargill, B. et al. One mont versus 6 months therapy with oral anticoagulants aftef symptomatic deep vein thrombosis. Acta Med Scand 1985음 218: 279-284.

16. Kutner, M., Nixon, G. \& Silverstone, F. Physicians attitude towards oral anticoagulant and antiplatelet agents for stroke prevention in elderly patients with atrial fibrillation. Arcks Intern Med 1991, 151: 1950-1953. 